\title{
Liver transplantation. Expectation with MELD score for liver allocation in Brazil ${ }^{1}$
}

\author{
Transplante hepático. Expectativas com escore MELD para \\ alocação de fígado no Brasil
}

\begin{abstract}
Andreza Correa Teixeira ${ }^{2}$, Fernanda Fernandes Souza ${ }^{2}$, Gustavo de Assis Mota ${ }^{3}$, Ana de Lourdes Candolo Martinelli ${ }^{4}$, Ajith Kumar Sankarankutty ${ }^{5}$, Orlando de Castro e Silva ${ }^{6}$

1. Study performed in the Liver Transplantation Unit of the Division of Gastroenterology of the Department of Surgery and Anatomy of Ribeirão Preto Faculty of Medicine - University of São Paulo - (FMRP-USP), Brazil.

2. Fellow Master degree, Member of the Liver Transplant Program of the Division of Gastroenterology of the Department of Surgery and Anatomy, (FMRP-USP), Brazil

3. MD, Assistant of Division of Gastroenterology of the Department of Surgery and Anatomy, (FMRP-USP), Brazil.

4. PhD, Professor of the Department of Medicine, (FMRP-USP), Brazil.

5. PhD, Professor of the Department of Surgery and Anatomy, Division of Gastroenterology. Operational coordinator of the Liver Transplant Program, (FMRP-USP), Brazil.

6. Full Professor, Head of Division of Gastroenterology of the Department of Surgery and Anatomy, Coordinator of the Liver Transplant Program, (FMRP-USP), Brazil.
\end{abstract}

\begin{abstract}
Liver transplantation represents the most effective therapy for patients suffering from chronic end-stage liver disease. Until very recently, in Brazil, liver allocation was based on the Child-Turcotte-Pugh score and the waiting list followed a chronological criterion. In February 2002 the Model for End-stage Liver Disease (MELD) score was adopted for the allocation of donor livers in the US. After that change, an increased number of patients with more severe liver disease was observed, although there was no difference in 1-year patient and graft survival. A reduction in waiting-list mortality was also observed. In Brazil, the MELD score was adopted on May 31 ${ }^{\text {st }}, 2006$. Good results are expected regarding the new criterion for allocation.
\end{abstract}

Key words: Liver Transplantation. MELD Score. Organ Allocation.

\section{RESUMO}

O transplante de fígado representa o tratamento mais eficiente disponível no momento para pacientes com doença hepática crônica terminal. Em fevereiro de 2002 o escore - Model for End-stage Liver Disease (MELD), o qual determina a gravidade da doença com estimativa de mortalidade em três meses, foi implantado para alocação de doadores de fígado nos Estados Unidos. Conseqüentemente foi observado um maior número de pacientes graves transplantados, com redução de mortalidade na lista de espera e não houve diferença de sobrevida em um ano de paciente e enxerto. Até recentemente no Brasil a alocação de órgãos era baseada no critério cronológico de acordo com a inclusão em lista de espera para transplante de fígado, doador cadáver. Há poucos dias (31 de maio de 2006), foi publicada a portaria que institui o critério de gravidade para alocação de fígado. Expectativas quanto aos resultados e o impacto dessa mudança na realidade brasileira são aguardados.

Descritores: Transplante de Fígado. Escore MELD. Alocação Órgãos.

The first successful liver transplantation in history was performed by Tomaz Starzl in $1967^{1}$ and, starting in 1983, after a consensus promoted by the United States National Institutes of Health, liver transplantation was no longer considered to be an experimental procedure but was indicated for the treatment of liver diseases. ${ }^{2}$ Nowadays, liver transplantation represents the most effective therapy for patients suffering from chronic end-stage liver disease. ${ }^{3}$ On September $1^{\text {st }}$, 1985, Silvano Raia performed the first successful liver transplant in $\mathrm{Brazil}^{4}$, and better results have been achieved over the last few decades based on careful patient selection, improved surgical and anaesthetic techniques, as well as advances in immunosuppressive therapy. In Ribeirão Preto, we initiated the Liver Transplantation Program on October, 2000, and the first clinical transplant was performed on the $1^{\text {st }}$ of may $2001 .{ }^{5,6}$ In the United States, according to data provided by the United Network for Organ Sharing (UNOS), about 10,000 patients were enrolled in 2004 and 5,842 liver transplants were performed using cadaveric donors. The mean waiting list death rate was approximately $6 \% .^{7}$ According to the Brazilian Health Ministry, in 2004 there were 57 transplant 
centers in the country, with 64 active teams. ${ }^{8}$ Patient selection for the allocation of cadaveric donor livers is currently based on decree $n^{0} 3,407$ of August 5, 1998, published in the Official Record 149 of August 6, 1998. The minimum requirements are: a) identity of the $\mathrm{ABO}$ blood system between donor and recipient; b) origin, when donor and recipient weigh less than $40 \mathrm{~kg}$; c) time since enrolment on the unified list. ${ }^{9}$ In 2004, the waiting list for a cadaveric donor in Brazil was of 6,313 enrolled candidates, with 2,964 additions during that year alone. During the same year, 935 liver transplants were performed in Brazil, with 757 organs being obtained from cadaveric donors. ${ }^{10}$ A total of 1,789 patients were enrolled in the state of São Paulo, in 2004, with 351 liver transplants from cadaveric donors and a waiting list mortality rate of $18.5 \%$. In 2005, a total of 295 liver transplants from cadaveric donors were performed in the same state. However, by the month of May 2006, the waiting list for the state of São Paulo was 4,102, corresponding the longest list in the country. ${ }^{11}$ This represents an increase in the number of new cases included, which exceeds the number of transplants performed, leading to a longer time on the waiting list. In Brazil as a whole, the average time on the waiting list is about 18.8 months, with a waiting list mortality rate of about $30 \%{ }^{12}$. In the state of São Paulo, time on the waiting list is approximately 51 months. ${ }^{8}$ It is clear that available organs are insufficient to satisfy the demand. This scenario showing the increasing need for organs has motivated debates in Brazil and in the whole world regarding the criteria for graft allocation. These discussions are important for a more equitable organ distribution in a situation of scarcity, until measures are adopted to improve organ acquisition. Current strategies for the optimization of organ acquisition include the use of reduced grafts, sequential transplant, and the use of marginal grafts, in addition to transplants between living subjects ${ }^{13}$, a surgical modality first described in Brazil in 1988 by Silvano Raia, in the state of São Paulo. We believe that cadavers are the best source of liver grafts since, in this way; a healthy individual is not submitted to the risks of major surgery. Thus, the use of a cadaver donor is indicated for all liver transplants and, for this to become a reality, we need to improve our organ procurement performance. Up to 100 patients per million inhabitants are expected to suffer brain death each year as a consequence of accidents or of intracerebral haemorrhage. This shows that there are large numbers of potential organ donors. Developed countries are able to obtain 20 to 40 donors per million inhabitants per year and countries close to Brazil, such as Argentina and Chile, achieve a rate of 10 to 12 donors per million inhabitants per year. In our country, the rate obtained is 3.7 donors per million inhabitants per year, a value much lower than that reported for the above countries. Statistical studies demonstrate a very low utilization of potential donors, i.e., patients admitted to Intensive Care Units with a diagnosis of brain death. Less than one quarter of these patients are converted to effective donors. The main reason is the lack of authorization for organ removal by the family, and the second main obstacle is the presence of medical contraindication regarding the potential donor, as a consequence of a delayed diagnosis of brain death or of inadequate clinical maintenance, causing the organs to be inappropriate for transplantation. ${ }^{14}$ The ideal time for the indication of liver transplantation is a difficult decision. The indication should occur at the time when the risk of death due to complications of liver disease exceeds the immediate or long-term mortality rate after transplantation, which in Brazil is about $35 \%{ }^{9}$. In the state of São Paulo, the actuarial survival for recipients of a liver transplant from a cadaver donor was $53.8 \%$ in $2005 .{ }^{11}$ To date, in our country the minimum seven point score of the Child-Turcotte-Pugh classification has been used for the indication of liver transplantation. When the score is less than seven, the patient should present at least one of the following complications: upper digestive haemorrhage with two or more distinct episodes and the need for blood replacement, hepatopulmonary syndrome with clinical manifestations, or portal-systemic encephalopathy. ${ }^{15}$ However, the Brazilian Health Ministry decreed, recently, that a new criterion for allocation of liver from cadaveric donors instituted in the country. ${ }^{16}$ The Model for End-stage Liver Disease MELD formula used to calculate the severity score is as follows: $3.8 \log _{\mathrm{e}}($ total bilirubin $\mathrm{mg} / \mathrm{dl})+11.2 \log _{\mathrm{e}}$ (International Normalized Ratio [INR]) $+9.6 \log _{\mathrm{e}}($ creatinine $\mathrm{mg} / \mathrm{dl})+6.4$. Minimal values for variables are set at 1.0 for calculation purposes. The maximal serum creatinine level considered within the MELD score formula is $4.0 \mathrm{mg} / \mathrm{dl} .{ }^{17}$ At the University Hospital of the Faculty of Medicine of Ribeirão Preto, University of São Paulo", 79 medical files were availed for analysis of Child-Turcotte-Pugh and MELD scores in January 2005. One year later, the deaths of patients on wait for liver transplantation and the number of transplantations performed in 2005 were identified. Sixty-three (80\%) of 79 patients on the waiting list for liver transplantation were Child B or C. The average MELD score was $10 \pm 5$ for Child A patients, $13 \pm 3.4$ for Child B patients and $21 \pm 4.3$ for Child $\mathrm{C}$ patients. Nine (11\%) deaths on the waiting list were notified in 2005. Of these, one patient was Child B and MELD 10 , while the others were Child $\mathrm{C}$, with an average MELD score of $21 \pm 3.8$. Twelve $(15 \%)$ patients received cadaveric orthotopic liver transplantation (OLT). During the study period, half of the Child $\mathrm{C}$ patients on the waiting list died. The patients with a MELD score higher than 20 shared a similar fate. Among the patients with a MELD score higher than $20,40 \%$ died on the waiting list, whereas $12.5 \%$ were transplanted. Thus, mortality on the waiting list depends on the length of waiting time as well as on the severity of the liver disease at the time of inclusion. We observed a motility rate of $11 \%$ in our waiting list, these being only the deaths notified to the Sao Paulo State Transplant System, which may represent a slight underestimate. On the other hand, among the deaths notifies, Child $\mathrm{C}$ patients and those with an average MELD score of 21 constituted the majority. Nevertheless, it is important to mention that the MELD scores were not calculed at the time of inclusion, but at varying times while on the waiting list. In the US, the MELD system for liver allocation started to be in force in February 2002 and significant changes in the dynamics of organ allocation have been observed since then. An increase in the number of patients with more severe disease was observed, but there was no difference in 1 year survival ${ }^{18,19}$ compared to previous criteria. In addition, waiting list mortality rate was reduced.$^{20}$ In Brazil, a recently published 
decree instituted the criterion of disease severity for liver allocation, witch started to be valid 30 days after publication. ${ }^{16}$ Analysis of the results and impact of change on the Brazilian reality is currently underway.

\section{References}

1. Everson GV, Trotter JF. Transplantation of the liver. In: Schiff ER., Sorrell MF, Maddrey WC. Diseases of the liver. 9ed. Philadelphia: Lippincott Williams \& Wilkins; 2002. p1585-614.

2. Bismuth $\mathrm{H}$. The need for a consensus agreement on indication of liver transplantation. Hepatology. 1994; 20:1S-2S.

3. Castro e Silva O, Sankarankutty AK, Oliveira GR, Pacheco E, Ramalho FS, Dal Sasso K, Tolentino E, Mente ED, França AVC, Martinelli ALC. Liver transplantation: indication and survival. Acta Cir Bras. 2002; 17(3):83-91. Available from URL: $<$ http://www.scielo.br/scielo $>$

4. Sette Junior H, Barros MFA, Cury RA, Pessoa MG, Osawa C. Transplante hepático: política de captação, alocação e distribuição de órgãos no Brasil. GED. 2000; 19(1): 28-36.

5. Castro e Silva, O. Primeiro transplante de figado em Ribeirão Preto. Medicina, Ribeirão Preto. 2001; 34:119-20.

6. Franca AVC, Martinelli ALC, Sankarankutty AK, Rizzo CC, Castro e Silva O. Tranplante de fígado: relato do primeiro caso realizado no Hospital das Clínicas da Faculdade de Medicina de Ribeirão Preto da Universidade de São Paulo. Medicina, Ribeirão Preto. 2001; 34:194-9.

7. Donors, Transplants, and Waiting List Additions, Deaths And Death Rates, Overall And By Region 05 may 2005. Produced by UNOS. Available from URL: $<$ http://www.unos.org/SharedContentDocuments/ 2005 spring.pdf $>$. Accessed May 14, 2005.

8. Reunião do Ministério da Saúde 17 Mar 2005. Produced by ABTO. Available from URL: $<$ http://www.abto.org.br/profissionais/departamentos/ relatorios/reuniao $>$. Accessed May 14, 2005.

9. Brasil. Ministério da Saúde. Seleção de pacientes para distribuição de fígado-doador cadáver. Portaria nº 3407 de 5 de agosto de 1998, publicada no Diário Oficial da União, no. 149 de 06 de agosto de 1998.
10. ABTO - Centros Transplantadores Cadastrados Ativos, Registro Brasileiro de Transplantes (RBT), 2005.

11. Sistema Estadual de Transplantes - Secretaria da Saúde de São Paulo. Available at: <http://www.saude.sp.gov.br/ portal/6a4f5365c89b06a7005976c293ab8667.htm>. Accessed April 26, 2006.

12. Massarolo PCB, Fernandes JH, Millan LS, Inacio CAF, Rodrigues Junior, AJ, Mies S. Efeito da escala MELD na mortalidade após o transplante de fígado. Jornal Brasileiro de Transplantes 2003; 6:14-20.

13. Miller CM, Rapaport FT, Starzl TE. Organ Procurement. In: Wilmore DW, Chueng LY, Harken AH, Holcroft JW, Meakins JL, Soper NJ. ACS Surgery: Principles and Practice. New York: WebMD Inc; 2003. p 995-1007.

14. Campos HH. Aumento do número de transplantes e da doação de órgãos e tecidos: processo de construção coletiva. Available at: <http://www.abto.org.br/ profissionais/profissionais.asp $>$. Accessed May 15, 2005.

15. Brasil. Ministério da Saúde. Critérios para Cadastramento de Candidatos a Receptores de Fígado - Doador Cadáver. Portaria $n^{\circ} .541$ de14 de março de 2002, publicada no Diário Oficial da União, $n^{\circ} .51$ de março 2002.

16. Brasil. Ministério da Saúde. Critério para distribuição de fígado doador cadáver para transplante. Portaria ${ }^{\circ} .1 .160$ de 29 de maio de 2006, publicada no Diário Oficial da União, nº 103 de 31 de maio de 2006.

17. Kamath PS, Wiesner RH, Malinchoc M, Kremers W, Therneau TM, Kosberg CL, D'Amico G, Dickson ER, Kim WR. A model to predict survival in patients with end-stage liver disease. Hepatology. 2001; 33:464-70.

18. Kanwal F, Dulai GS, Spiegel BM, Yee HF, Gralnek IM. A comparison of liver transplantation outcomes in the prevs. post-MELD eras. Aliment Pharmacol Ther. 2005; 21:169-77.

19. Yoo HY, Thuluvath PJ. Short-term post liver transplant survival after the introduction of MELD scores for organ allocation in the United States. Liver Int. 2005; 25:536-41.

20. Freeman RB, Wiesner RH, Edwards E, Harper A, Merion $\mathrm{R}$, Wolfe R. Results of the first year of the new liver allocation plan. Liver Transpl. 2004; 10(1):7-15.
Correspondence:

Orlando de Castro e Silva Jr.

Rua Campos Salles, 809/9 andar

14015-110 Ribeirão Preto - SP Brazil

orlando@fmrp.usp.br

\section{How to cite this article:}

Teixeira AC, Souza FF, Mota GA, Martinelli ALC, Sankarankutty AK, Castro e Silva O. Liver transplantation: expectation with MELD score for liver allocation in Brazil. Acta Cir Bras. [serial on the Internet] 2006;21 Suppl 1. Available from URL: http://www.scielo.br/acb 